Research Article

\title{
EVALUATION OF RENEWABLE ENERGY SOURCE ALGAE AS BIODIESEL FEEDSTOCK
}

\section{Fevzi YAŞAR}

World population growth, together with urban development and industrialization, is increasing the world primary energy consumption every passing day. It is known that most of the energy used worldwide is derived from fossil fuels such as coal, oil and natural gas, which are called primary energy sources. In this context, as humanity continues to search for sustainable development and better living conditions, renewable energy production becomes a worldwide priority. Renewable energy has an extremely important place in respect to meeting the energy needs of countries with domestic resources, thus reducing foreign dependencies, by diversifying resources and ensuring sustainable energy use and minimizing the damage to the environment as a result of energy consumption. Within the context of alternative energy policies, agriculture-based biomass energy has found a wide application area all over the world, with environment-friendly, sustainable energy production and environmental management features aimed at development. However, the increasing production of biofuels due to the agricultural potential and technological levels of the countries has brought significant debates with it. In this case, scientists have voiced that algae biomass, defined as third generation, could be an alternative energy source and that they have many advantages. From algae biomass; studies on biofuels such as biodiesel, renewable aviation fuel / bio jet fuel, bio- gasoline I green gasoline, bio-butanol, bioethanol, methane has been widely developed. It is a very important development that the agricultural areas are not used during the cultivation of the algae, and that they can reproduce with great speed even in very small areas.

Key words: Renewable energy source, vegetable oils, algae oil, biodiesel feedstock - Word Style TS Abstract

\section{Introduction}

Energy is one of the most basic and influential requirements of the economic and social development of a country. From this standpoint, "energy security" phenomenon is a vital element of economic security and national security [1]. Energy is an indispensable input for almost all processes necessary for us to sustain our social lives; accordingly, it is used in industry, transportation, residential

\footnotetext{
${ }^{1}$ Vocational School of Technical Sciences, Department of Chemistry and Chemical Process Technology, Batman University, 72100, Batman, Turkey, (fevzi.yasar@batman.edu.tr), Đhttps://orcid.org/0000-0003-3504-9157 
and commercial sub-sectors. While the energy consumed in the world today is derived from a large number of energy sources, fossil resources such as oil, natural gas and coal account for $87 \%$ of these sources [2]. Population and income growth are the main factors causing the increase of world primary energy consumption. Population growth is predicted to have a significant impact on global energy demand growth, depending on emerging industries and urbanization [3]. According to the scenarios, it is predicted that these fuels will continue to be dominant sources despite their relatively decreasing share up to 2040 [4].

\subsection{The Situation of Petroleum in the World and in Turkey}

It is known that most of the energy used in world is derived from fossil fuel sources such as coal, oil and natural gas, which are called primary energy sources, and the increase in primary energy demand is accelerating due to the increase in income and population in the world. It is known that oil has the largest share in the world's primary energy consumption, especially as the main energy source of the transportation sector [5]. When the geographical distribution of oil reserves is assessed, it appears that the entire world is dependent on the Middle East for its oil reserves. Instabilities occurring in the Middle East lead to difficulties in the uninterrupted supply of petroleum, which is a major necessity of the modern world. When geographical distribution of global oil reserves is looked through, the Middle East region draws attention as having $47.66 \%$ of world oil reserves. The Middle East is followed by Central and South America with a reserve of $19.23 \%$ and North America with a reserve of $13.31 \%$. In addition, the areas, such as Europe and Eurasia, Africa and Asia -Pacific, have the shares of global oil reserves as $9.50 \%, 7.50 \%$ and $2.81 \%$, respectively. In terms of visible / proven oil reserves of the countries, with 300 billion barrels, Venezuela takes place at the first place, and this country is followed by Saudi Arabia with 269 billion barrels, Canada with 171 billion barrels and Iran with 157.8 billion barrels and Iraq with 143 billion barrels. Turkey, by its geopolitical position, is neighbor with countries possessing three-quarters of world's proven oil and natural gas reserves; and takes place in many important projects together with the energy-rich Caspian, Central Asia, Middle East countries as a natural "Energy Center" located in among the consumer markets in Europe, and supports the projects in question. It is envisaged that a significant portion of the world's primary energy demand, which is expected to increase by $40 \%$ by 2030 , will be met from the resources of the region we are in [6]. At the end of the first six months of 2017, the remaining domestic crude oil reserves are 332.8 million barrels (48 million tons). If no new discoveries are made, the current production level and the total domestic crude oil reserves have an 18 year life span. In the first five months of 2017, approximately $7.7 \%$ of consumption was covered by domestic production. Turkey's primary energy consumption in the years 2010-2016 (except for 2008) is constantly rising, the share of primary energy consumption of oil and natural gas hovered around $60 \%$. In 2016, the share of oil and natural gas consumption in primary energy was $57.4 \%$.

In 2016, the total consumption rate of domestic crude oil production was $5.8 \%$. In the first six months of 2017, a total of 1.3 million tons of crude oil was produced; and a total of 150 million tons of crude oil has been produced till present day. Despite the fact that the raw material and energy resource capacities of our country are limited due to the information given above, the continuous and rapid increase in the raw material and energy needs with the use of new technological products entering our lives every day forces humanity to find new alternative energy sources. Alternative sources need to be human-focused, renewable, feasible, and easily obtainable with sustainable economic development and domestic resources for a cleaner environment. For this reason, the use of renewable energy resources in the form of both local and renewable natural resources is of great importance in meeting the energy 
needs of both our country and the rest of the world. That is why a tendency has begun to focus on renewable energy sources all over the world both in terms of technological researches and using the energy produced from these sources. Countries concentrate on various renewable energy sources (biomass, solar, wind, hydroelectric, geothermal, wave etc.) depending on their economic, environmental, natural and social characteristics. Within the context of alternative energy policies, agriculture-based biomass energy has found a wide application area all over the world, with environment-friendly, sustainable energy production and environmental management features aiming at development. However, the increased production of biofuels due to the agricultural potential and technological levels of the countries has brought about some significant debates. In this case, scientists have voiced that algae biomass, defined as third generation, could be an alternative energy source, and that they have many advantages. Biomass energy research, which has accelerated in recent years with the effect of rising oil prices, has begun to be seen as a source of energy promising hope. Studies, where biofuels such as biodiesel, renewable aviation fuel / bio jet fuel, bio gasoline / green gasoline, biobutanol, bioethanol, methane are obtained from algae biomass, have been widely developed. By using algae oils as raw materials in the production of biodiesel, both the biodiesel unit price can be competitive with the petroleum origin diesel fuel and it will be possible to diversify the energy sources of the countries and the countries will be able to get rid of the external dependence in terms of energy. The studies have indicated that biodiesel fuel obtained from renewable sources such as vegetable and animal fats can be used as an alternative to the petroleum diesel and thus is considered as a promising alternative fuel for reducing petroleum dependence and reducing pollution caused by exhaust emissions [7].

\section{Biodiesel Production and Properties}

To be able to use vegetable and animal oils as alternative fuels in diesel engines, it is necessary to lower the biodiesel viscosities, which are very high, compared to petroleum origin diesel fuel (diesel) [8]. For this purpose, dilution, micro emulsion formation, pyrolysis and transesterification methods are used. In the dilution method, the oil is diluted by mixing with diesel fuel [9]. Depending on the mixture of diesel fuel ratio, the fuel improves in terms of viscosity, evaporation, spraying properties. In micro emulsion formation, it is intended to form micro emulsions with short chain alcohols such as methanol, ethanol or 1-butanol. The micro emulsion is the equilibrium distribution of optically isotropic liquid microstructures with dimensions between 1 and $150 \mathrm{~nm}$, normally formed by the mixing of two immiscible liquids and one or more active substances. In pyrolysis method, however, oil molecules are broken down into smaller molecules in an oxygen-free environment at high temperatures. Pyrolysis process is divided into three parts as hydrocracking, catalytic cracking and thermal cracking. The amount of product produced depends on the method and reaction parameters used. With this method, although the fuel properties of oils approach diesel fuel properties, the most important drawback is high energy consumption. Transesterification is the re-esterification reaction of fatty acids (vegetable oils, domestic waste oils, animal oils) with alcohol (methanol, ethanol, etc.) in the presence of a basic catalyst. In this method, oil molecules enter into a chemical reaction with alcohol at a certain temperature with the help of a catalyst. With this chemical reaction, the fatty acids separate from the triglycerides they are bound to form new esters with alcohols [9].

\subsection{Reaction mechanism in biodiesel production by transesterification}

Transesterification is an ester conversion process that breaks down triglycerides that form vegetable and animal fats, in other words, by taking the glycerol in it and replacing it with the alkyl 
radical in the alcohol used. Briefly, glycerol-based triesters are converted to alkyl-based monoesters. With transesterification, the conversion of triglycerides into monoesters results in a molecular weight of about one third, and a major problem, the high viscosity, is greatly reduced. In addition, the volatility feature is also improved [10]. Alcohol: the raw material molar ratio for the stoichiometric transesterification reaction is $3: 1$, and since transesterification is a reversible equilibrium reaction, it is necessary to use more alcohol in theory to be able to move the reaction towards the products. For this reason, in practice, alcohol with molar ratios greater than 3: 1 is used. Generally, when $100 \%$ excess alcohol (6: 1) is used, the reaction rate and ester conversion are obtained at the highest level. Howe ver, increasing the ratio of alcohol more than a certain value does not improve the ester conversion, but prevents the decomposition of glycerol. Moreover, at the end of the reaction, it is necessary to remove the residual alcohol from the reaction environment, which adds extra cost to the system [11]. The alcohol used is very important because it affects both the transesterification reaction and the properties of the biodiesel fuel obtained. Biodiesel is an ester fuel called the alkyl part of the alcohol used in the production. If methanol is used in the reaction, the fuel is defined as the methyl ester; and it is called as ethyl ester fuel if ethanol is used. It also contains the alcohol bonds used in the biodiesel production and thus the fuel properties are affected by this. Among the alcohols used in the transesterification reaction, methanol is preferred because of its low cost and physical-chemical advantages (polar and shortest chain alcohol). Methanol reacts rapidly with triglycerides and the catalyst readily becomes soluble in

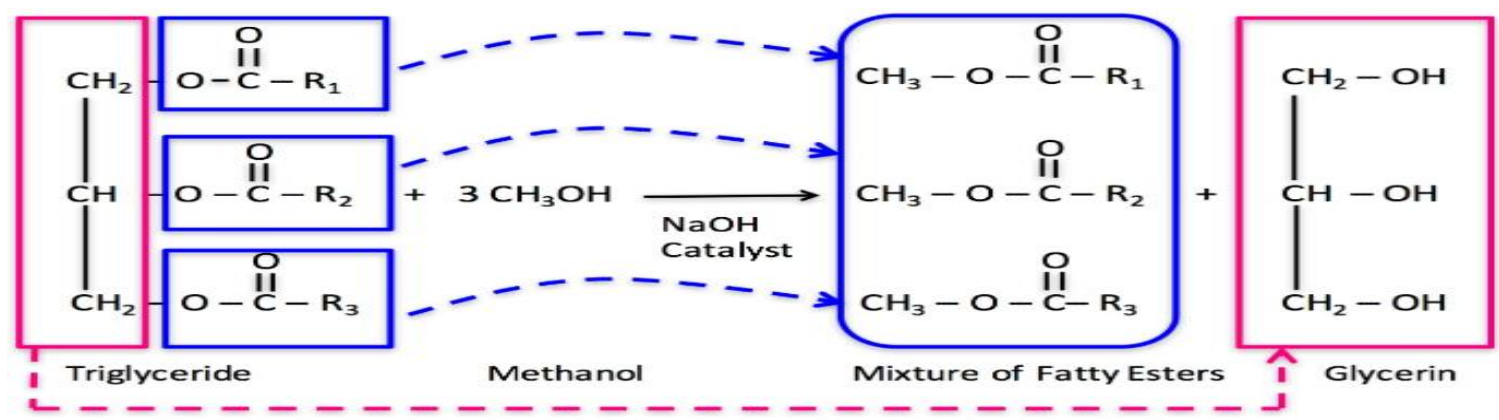

methanol. Biodiesel is made through a chemical reaction called transesterification (Fig. 3) where fats and oils are converted into a mixture of fatty acid methyl esters (FAME) in a presence of alcohol with base catalyst.

Figure 3. Transesterification reaction for biodiesel production [12]

The base, acid or enzyme (biological) catalyst is used as a catalyst to accelerate the transesterification reaction. Acid and enzyme catalysts are slower than base catalysts [11].

\subsection{Biodiesel Properties}

Biodiesel, like vegetable and animal fats, is a promising alternative diesel fuel derived from renewable sources that contains oxygen and is particularly promising in terms of reducing polluting exhaust emissions [13]. Biodiesel is a methyl or ethyl ester type fuel containing medium chain C16-C18 fatty acid chains. It does not contain toxic wastes, it dissolves rapidly in nature like sugar, and it reduces the need for fertilization by its nitrogen retention feature. The adverse effects on the ozone layer are $50 \%$ less than diesel fuel. Biodiesel is an environmentally friendly, anti-toxic, biologically fast and easily degradable fuel that can be obtained from renewable raw materials. At the same time, with low content of sulfur and high flash point, it is a kind of fuel which can be easily stored, and is portable and usable. It also has an excellent lubrication feature. Biodiesel and its diesel fuel mixtures can be used in 
diesel engines without any technical modifications or minor changes [14]. This feature raises the quality of petroleum-derived diesel. For example, it reduces the emission values of harmful gases generated by combustion, increases the degree of lubrication on the motors and dissolves accumulators that reduce motor power. Since biodiesel is derived from agricultural crops in general, it does not have an increasing the greenhouse effect as it converts $\mathrm{CO} 2$ into food by photosynthesis and accelerates the carbon cycle in the biological carbon cycle. In other words, biodiesel can be considered as a natural sink for $\mathrm{CO}_{2}$ emissions. For the biodiesel, the European Union of EN 14214 and the American Standard of ASTM D 6751 are in force. TSA Standard in Turkey has been prepared based on EN 14214 standard. In Table 3, the specifications that the biodiesel produced in Turkey should provide for the TS according to EN 14214 standards are given.

Table 3. EU (EN 14124: 2013) biodiesel standard [15].

\begin{tabular}{|c|c|c|c|}
\hline Properties & Unit & Limit Values & Test Method \\
\hline Esther content & $\%(\mathrm{~m} / \mathrm{m})$ & 96.5 & EN 14103 \\
\hline Density $\left(15^{\circ} \mathrm{C}\right)$ & $\mathrm{kg} / \mathrm{m}^{3}$ & $860-900$ & EN ISO 12185 \\
\hline Kinematic viscosity $\left(40^{\circ} \mathrm{C}\right)\left(40^{\circ} \mathrm{C}\right)$ & $\mathrm{mm}^{2} / \mathrm{s}$ & $3.50-5.00$ & EN ISO 3104 \\
\hline Flash Point & ${ }^{\circ} \mathrm{C}$ & $101 \mathrm{~min}$. & EN ISO 3679 \\
\hline Sulfur content & $\mathrm{mg} / \mathrm{kg}$ & 10 max. & EN ISO 20846 \\
\hline Carbon residue & $\%(\mathrm{~m} / \mathrm{m})$ & 0.30 & EN ISO 10370 \\
\hline Cetane number & & $51 \mathrm{~min}$. & EN ISO 5165 \\
\hline Sulphate ash content & $\%(\mathrm{~m} / \mathrm{m})$ & $0.02 \max$ & ISO 3987 \\
\hline Water content & $\mathrm{mg} / \mathrm{kg}$ & 500 max. & EN ISO 12937 \\
\hline Total pollution & $\mathrm{mg} / \mathrm{kg}$ & 24 max. & EN 12662 \\
\hline Copper strip corrosion & Corrosion & No 1 max. & EN ISO 2160 \\
\hline Oxidation stability $\left(110^{\circ} \mathrm{C}\right)$ & Hour & $8.0 \mathrm{~min}$. & EN 14112 \\
\hline Acid value & $\mathrm{mg} \mathrm{KOH} / \mathrm{g}$ & $0.5 \max$ & EN 14104 \\
\hline Iodine value & $\mathrm{g} \mathrm{I}_{2} / 100 \mathrm{~g}$ & $120 \max$. & EN 14111 \\
\hline Linolenic acid methyl ester & $\%(\mathrm{~m} / \mathrm{m})$ & $12 \max$ & EN 14103 \\
\hline High unsaturation $(\geq 4$ double & $\%(\mathrm{~m} / \mathrm{m})$ & $1 \max$. & EN 15779 \\
\hline Methanol content & $\%(\mathrm{~m} / \mathrm{m})$ & 0.20 max. & EN 14110 \\
\hline Monoglyceride content & $\%(\mathrm{~m} / \mathrm{m})$ & $0.80 \max$. & EN 14105 \\
\hline Diglyceride content & $\%(\mathrm{~m} / \mathrm{m})$ & $0.20 \max$ & EN 14105 \\
\hline Triglyceride content & $\%(\mathrm{~m} / \mathrm{m})$ & 0.20 max. & EN 14105 \\
\hline Free glycerol & $\%(\mathrm{~m} / \mathrm{m})$ & $0.02 \max$. & EN 14105 \\
\hline Total glycerol & $\%(\mathrm{~m} / \mathrm{m})$ & $0.25 \max$ & EN 14105 \\
\hline Group I Metals $(\mathrm{Na}+\mathrm{K})$ & $\mathrm{mg} / \mathrm{kg}$ & $5.0 \max$ & EN 14108 \\
\hline Phosphor content & $\mathrm{mg} / \mathrm{kg}$ & $4.0 \max$. & EN 14107 \\
\hline
\end{tabular}

\section{Advantages and Disadvantages of Using Biodiesel}

The most important advantage of using biodiesel as alternative engine fuel is that it can be used in existing diesel powered vehicles. In other words, there is no need to make any changes or additions to the engine construction to use biodiesel as fuel in the engines available. As is known, parallel to the developments in diesel engine technology, the number of vehicles with diesel engines also increases and its use in automobiles is becoming more widespread. Like other alternatives (such as hydrogen, LPG, $\mathrm{CNG}$ ), since biodiesel does not necessitate an additional system, this makes it an attractive alternative fuel. Biodiesel has many positive features and potentials directly, indirectly and possibly. 


\subsection{Advantages of biodiesel}

- Biodiesel-forming C16-C18 methyl esters are easily and rapidly disintegrated. They are biodegradable and non-toxic. According to the tests performed, $99.6 \%$ of the biodiesel obtained from the canola was decomposed in 21 days. It is an environmentally friendly alternative energy source, and has edible character, can be produced with local opportunities. When compared to diesel, it does not cause the accumulation of $\mathrm{CO} 2$ in the atmosphere and consequently the greenhouse effect. This is because the resulting $\mathrm{CO} 2$ from the combustion of biodiesel is used by plants where biodiesel is obtained [16].

- It allows making use of used domestic and industrial oils. It can be produced from waste vegetable and animal oils and fats. Assessment of waste materials reduces the amount of waste on the earth. It gives agricultural crops a second surplus value [17].

- Fatty acids and oils containing them in biodiesel have the highest thermal value in all biological materials. This property is the feature of relatively long hydrocarbon chain linked to a single carboxyl group bearing two hydrogen atoms. For this reason, vegetable oils are the closest biomass to liquid fuels and fatty biomaterials with higher heat energy than lean biomass provide a constant potential for biodiesel production [18].

- Biodiesel has a higher ignition rate $\left(>110^{\circ} \mathrm{C}\right)$ than petroleum-derived diesel fuel. Although this does not directly affect combustion, it makes biodiesel safer in terms of storage and portability [19].

- Emissions have less carbon monoxide, particulate matter, unburned hydrocarbons and aromatic compounds and almost no sulfur. Furthermore, it is also poor in terms of cancer causing compounds (Aromatics). Since biodiesel does not contain sulfur, it can be used as an oxidation catalyst in biodiesel plants. Thus, harmful emission values can be lowered to even lower levels.

- Biodiesel has a better lubricant than the engine, which prolongs engine life. Because the degree of lubrication is high [20].

- Biodiesel contains $11 \%$ oxygen by weight. The higher the oxygen content, the higher the combustion efficiency [16].

- Biodiesel has a very low iodine count, so it does not form any soot [21].

- The fact that it has higher cetane number compared to the diesel provides the engine with the less noise and without knocking operation. Biodiesel can be used in $100 \%$ ratio as well as being mixed with diesel fuel at various ratios in any unchanged diesel engines [22].

- Commercial glycerin and potassium fertilizer is obtained from biodiesel as by-product.

- In addition to accelerating the agricultural development of the countries with the impact of agriculture by providing integration of industrialization with agricultural products, new employment opportunities are created with the use of biodiesel, and contributions that cannot be underestimated by the country's economy are realized [21].

\subsection{Disadvantages of biodiesel}

- Biodiesel has a higher flow point than a diesel. The main factor affecting the use of vegetable oils directly as diesel fuel is their high viscosities. Injection systems of modern diesel engines show sensitivity to viscosity changes. The high viscosity spoils atomization of the fuel in the combustion chamber, preventing full combustion by growth in droplet size. Uncompleted combustion leads to deposits in the combustion chamber, in the injectors causing coking and 
blockage; besides, it negatively affects the lubricating oil by thickening and gelling it. Another problem with the use of vegetable oils as fuel originates from unsaturated bonds. The fact that unsaturated structures mix into the lubricating oil and are polymerized in this environment causes viscosity increases which are possible to destroy the engine [18].

- Biodiesel is affected more quickly by cold weather than by diesel. It has a higher cloud point in cold weather. Biodiesel containing high amounts of saturated fatty acids can cause blockage of fuel filter and fuel line pipes in winter. This is a limiting factor of biodiesel to be used in cold climate regions. In order to overcome this challenge, use of mixture form is preferred and the problem can be removed by preheating. Biodiesel is low by thermal value. This leads to some power drop in the resultant combustion [16].

- It has a high gel point. It is $0^{\circ} \mathrm{C}\left(32^{\circ} \mathrm{F}\right)$ for $\mathrm{B} 100(100 \%$ biodiesel $)$ and $-26^{\circ} \mathrm{C}\left(-15^{\circ} \mathrm{F}\right)$ for $\mathrm{B} 20$ (20\% biodiesel $+80 \%$ diesel) $[23]$.

- Another disadvantage of biodiesel is its tendency towards oxidation. Biodiesel in contact with air starts to oxidize rapidly, especially at high temperatures. Biodiesel, however, has a higher flash point. Although this does not directly affect burning, it makes biodiesel safer in terms of storage and portability [23].

- Biodiesel breaks up natural and butyl rubbers in storage, transport and engine equipment and cannot be stored for long periods. In the case of pure (B100) use, the hoses, fittings and gaskets in the fuel equipment in the engine should be replaced with appropriate materials [24].

\section{Utilization of Algae Oils in Biodiesel Production}

Algae (single-celled microalgae) are living organisms capable of performing microscopic photosynthesis on the land and in the sea. They are regarded as living things that have enabled life to start and be transferred to land by scientists, and they are said to have existed for almost 5 billion years. It is known that about 200,000 to 2-3 million species of algae in the nature have been recorded, and until now, about 30,000 species have been recorded and only a few of them could be commercialized [25]. Algae are rich in carbohydrates, proteins and especially fatty acids. Highly nutritious algae are the most important source of nutrients, vitamins and trace elements for the aquatic creatures. They also provide essential pigments for the development of coloring in fish and other aquatic life. Algae play an important role in protecting the integrity of all ecosystems. Diatoms and other microscopic algae in the oceans produce two thirds of the photosynthetic carbon needed by the entire world. In addition to photosynthetic vitrification carried out by sea algae in the water, it also meets the needs and nutrients and protection of creatures living in the water. Since the end of the 17th century, it has been known that the "potas", which are used to make soap, glass, soda and fertilizer, are obtained from their mineral rich ashes by the burning of brown moss. Bromine and iodine, which are among the chemical substances, have been isolated for the first time from this ash, and it is known that iodine is still obtained from marine algae in Japan. Algae are important food source, especially in eastern Asia. They are rich in A, B1, B2, B6 and C and niacin, iodine, potassium, iron, magnesium and calcium. Some algae varieties are cultivated as "support nutrients" and packaged and sold. Approximately 70 in China and 20 algae types in Japan are used meals [26]. Table 4 gives the lipid content, lipid productivity, volumetric and areal yields of biomass of some algae species used in biofuel production [27]. 
Table 4. Lipid content and productivity of different algae species

\begin{tabular}{|c|c|c|c|c|}
\hline Algae species & $\begin{array}{l}\text { Lipid content } \\
\text { (\% Dry Wt.) }\end{array}$ & $\begin{array}{l}\text { Lipid yield } \\
\text { (mg/L/day) }\end{array}$ & $\begin{array}{c}\text { Biomass Volumetric } \\
\text { yield (mg/L/day }\end{array}$ & $\begin{array}{l}\text { Biomass Sparse yield } \\
\left(\mathrm{mg} / \mathrm{m}^{2} / \text { day }\right)\end{array}$ \\
\hline Ankistrodesmus sp. & $24-31$ & - & - & $11.5-17.4$ \\
\hline Chlorella emersonii & $25-63$ & $10.3-50$ & $0.036-0.041$ & $0.91-0.97$ \\
\hline Chlorella vulgaris & $5-58$ & $11.2-40$ & $0.02-0.20$ & $0.57-0.95$ \\
\hline Chlorella sp. & $10-48$ & 42.1 & $0.02-2.5$ & $1.61-16.4$ \\
\hline Chlorella pyrenoidosa & 2 & - & $2.90-3.64$ & $72.5-130$ \\
\hline Chlorella & $18-57$ & 18.7 & - & $3.5-13.9$ \\
\hline Dunaliella salina & $6-25$ & 116 & $0.22-0.34$ & $1.6-3.5 / 20-38$ \\
\hline Dunaliella primolecta & 23.1 & - & 0.09 & 14 \\
\hline Haematococcus & 25 & - & $0.05-0.06$ & $10.2-36.4$ \\
\hline Nannochloropsis sp. & $12-53$ & $37.6-90$ & $0.17-1.43$ & $1.9-5.3$ \\
\hline Porphyridium cruentum & $9-18.8$ & 34.8 & $0.36-1.50$ & 25 \\
\hline Scenedesmus sp. & $19.6-21.1$ & $40.8-53.9$ & $0.03-0.26$ & $2.43-13.52$ \\
\hline Spirulina platensis & $4-16.6$ & - & $0.06-4.3$ & $1.5-14.5 / 24-51$ \\
\hline Spirulina maxima & $4-9$ & - & $0.21-0.25$ & 25 \\
\hline Tetraselmis suecica & $8.5-23$ & $27-36.4$ & $0.12-0.32$ & 19 \\
\hline
\end{tabular}

\subsection{Fuels produced from algae oils}

Algae have been produced or evaluated as food additives in animal breeding rather than as an alternative source of energy for many years. As a result of biomass energy research, which accelerated in recent years with the effect of rising oil prices, algae have begun to be seen as a promising source of energy. Despite being successful in laboratory research, pilot and small-scale experiments, the desired yield cannot be achieved in the case of the ideal processes in large-scale local production, if it is not possible to produce ideal processes in the field in the studies targeting to use many algae in nature used as energy source also called third generation biofuel technology. In general, algae can contain about 15 $77 \%$ oil, albeit varying by species. The fact that algae have high oil content and growth yields compared to other oil plants makes microalgae attractive for biodiesel and biogas production. The production of these fuels from microalgae has the potential to contribute to the prevention of global warming by responding to increasing global energy needs and, in part, by transforming excess carbon dioxide into an efficient product through photosynthesis in the atmosphere. One of the advantages of using mosses as raw materials for biofuels is that different kinds of fuels can be produced. Besides, algae have properties that can meet our needs for biodiesel and biogas as well as ethanol, bio jet fuel, bio-gasoline or other fuels [28].

Below are some types of fuel produced from algae:

-Biodiesel • Renewable Aviation Fuel / Bio jet Fuel

-Biobutanol • Bioethanol

-Bio gasoline / Green Gasoline,

-Methane

Biodiesel is a diesel fuel derived from plant or animal lipids (liquid or solid oils). Studies show that some algae types contain $80 \%$ more oil of their total dry weight. The majority of algae cells have largescale biomass production capacities because they are grown with water, $\mathrm{CO} 2$ and dissolved nutrients in the aqueous suspension medium in pools and photo bioreactors. Oil produced from algae can then be used as biodiesel in automobiles [29]. Figure 4 shows the production of bio-fuels and various biofuels resulting from oil extraction from algae grown by using wastewater such as agricultural or sewerage in plants established alongside the power plant. 


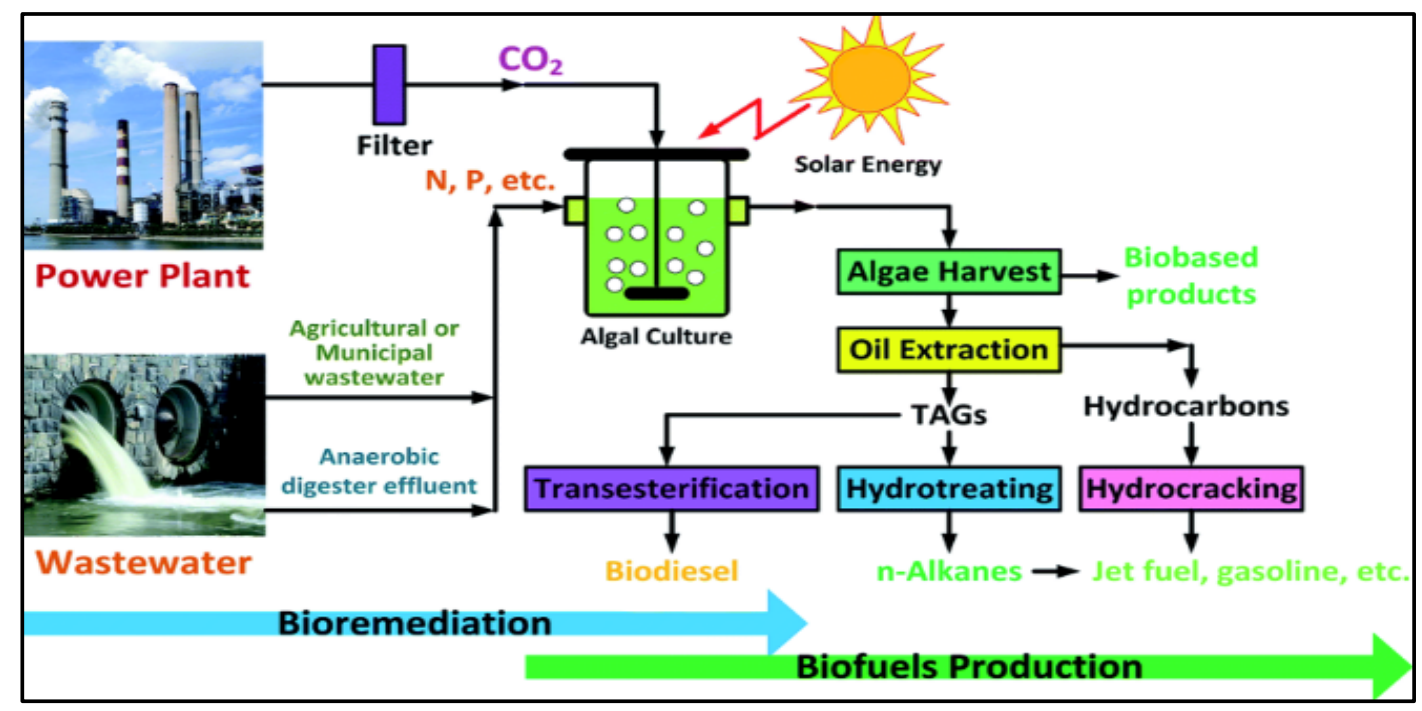

Figure 4. Production of biodiesel from algae biomass grown in wastewater [30]

\section{Use and Advantages of Seaweed Oil as an Energy Source}

The oil obtained from algae can be used directly as a fuel in diesel engines, just like other vegetable oils, and can be converted to biofuels by purification. The algae are observed in the laboratory environment that they increase the amount of oil produced by $40 \%$ because they are fed with more $\mathrm{CO}_{2}$ and organic substances. Seaweed oil, especially used in biodiesel production, can be used as an organic and environmentally friendly fuel. According to oil plants, algae produce organisms that make use of sunlight and $\mathrm{CO} 2$ more effectively, and their cleavage potentials and growth rates are also quite high. Some algae contain up to $60 \%$ by their weight of oil and can produce about 55,000-60,000 liters of oil per hectare per day if optimum conditions are met. For these reasons, it is possible to produce mosses in smaller areas, in larger quantities and at lower costs, compared to oil farms that have been cultivated extensively. The advantages of using algae oil as an energy source are given below:

- The fact that biodegradation of $\mathrm{CO} 2$ in industrial flue gases by algae and the transformation of grown algae oil into biodiesel take place reduces the effect of greenhouse gases in the atmosphere [31].

- Because they can be grown photo synthetically, they do not need carbon sources and use carbon dioxide as the energy source of previous consumption products to achieve carbon dioxide neutralization [32].

- Biodegradation of $\mathrm{CO} 2$ in industrial flue gases by algae and the transformation of grown algae and therefore oil into biodiesel reduces the effect of greenhouse gases in the atmosphere [30].

- Because they can develop photo synthetically, they do not need carbon sources and use carbon dioxide as the energy source of previous consumption products to achieve carbon dioxide neutralization [33].

- The lipids accumulated by the microalgae are generally in the form of triacylglycerol (> 80\%) and contain fatty acids C16-C18 rich in carbon atoms, which is also evident in the fatty acid distribution of the oil we use. The average lipid content of algae cells varies between $1 \%$ and $70 \%$, but there are also $90 \%$ lipid-accumulating algae when optimum conditions are met. 


\section{Results and Discussion}

The contents of oils used in production of biodiesel and the oil amount obtained per hectare/year and the area as $\mathrm{m}^{2}$ necessary for one liter biodiesel production and biodiesel amounts obtainable per hectare/year were investigated.
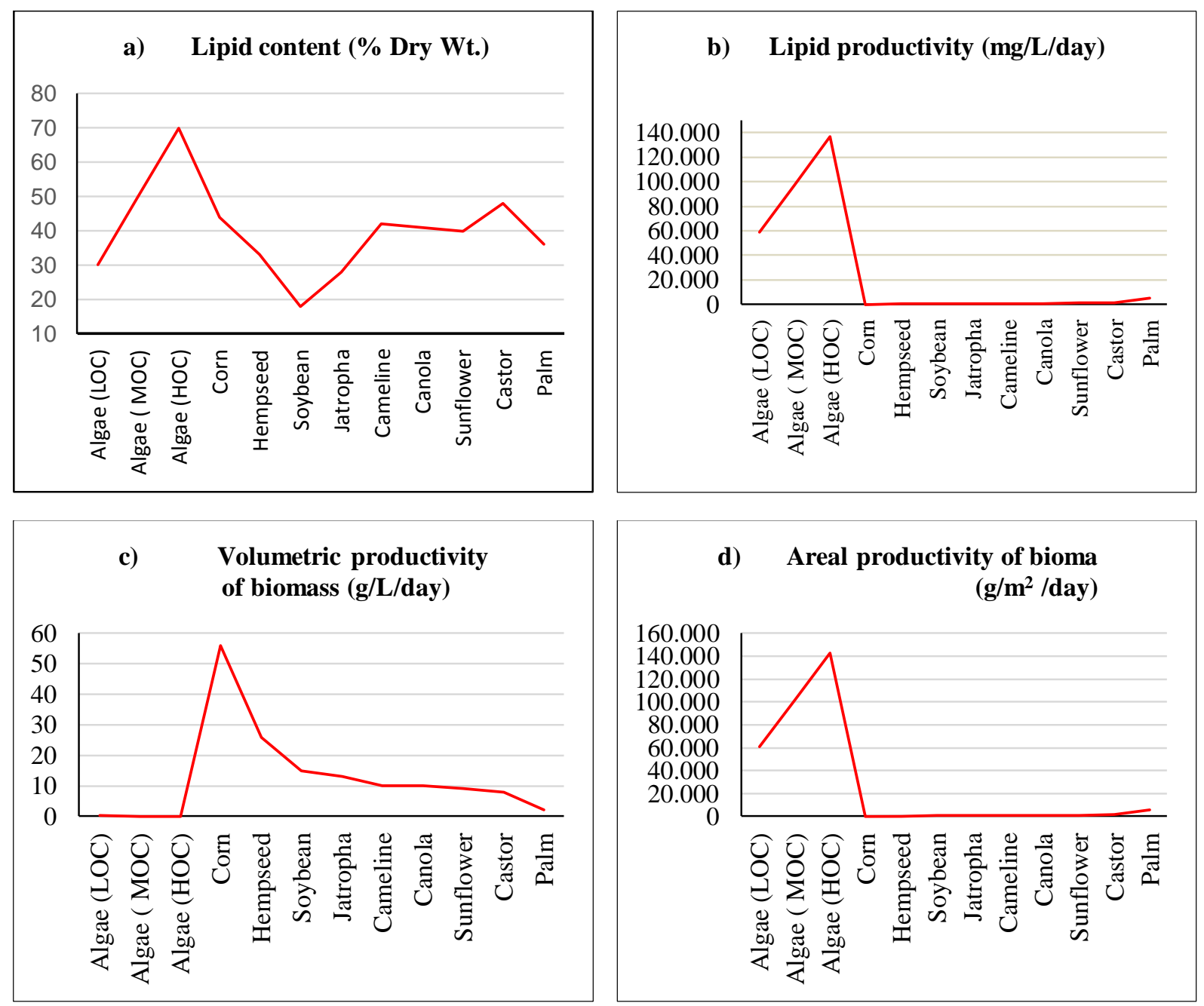

Figure 5. Oil content, oil yield, usage area and biodiesel yields of different vegetable oils used in biodiesel production. (LOC: Low oil content, MOC: Medium oil content, HOC: High oil content)

When Figure 1 is examined, it can be seen that algae HOC have the highest oil content with 70\%; and this is followed by algae MOC and jute with $50 \%$ and $48 \%$, respectively. It is known that algae types such as "Chlorella emersii" have quite oil contents in biodiesel production [vv]. When Figure 1b, d) is examined, it is determined that algae (HOC, MOC and LOC) have had higher yields compared to other resources in oil and biodiesel obtained per hectare/year. When Figure $1 \mathrm{c}$ ) is examined, it is seen that while Algae HOC necessary to produce 1 liter biodiesel is $0,1 \mathrm{~m} 2$, it is $56 \mathrm{~m} 2$ for maize. This clearly shows that algae are the most appropriate sources for biodiesel production. The density, viscosity and acid values, and some critical fuel properties such as peroxide value, saponification value, total particle matter (TPM) and calorific value of oils to be used in biodiesel production were analyzed in TÜPRAŞ Batman Refinery fuel analysis laboratory and in Batman University Technical Sciences Vocational College, Refinery and Petrochemical Technology Program laboratory. In Table 5. some of the critical properties of various herbal oils were given. 
Table 5. Some critical fuel properties of vegetable oils used in the study

\begin{tabular}{lcccccccc}
\hline Oils & $\begin{array}{c}\text { Density } \\
\left(\mathbf{k g} / \mathbf{m}^{\mathbf{3}} \mathbf{1 5}{ }^{\circ} \mathrm{C}\right)\end{array}$ & $\begin{array}{c}\text { Viscosity } \\
\left(\mathbf{m m}^{\mathbf{2}} / \mathbf{s}, \mathbf{4 0}{ }^{\circ} \mathrm{C}\right)\end{array}$ & $\begin{array}{c}\text { Acid Value } \\
(\mathbf{m g ~ K O H} / \mathbf{g})\end{array}$ & $\begin{array}{c}\text { lodine } \\
\text { Value } \\
(\mathbf{g ~ l} \mathbf{2} / \mathbf{1 0 0 g})\end{array}$ & $\begin{array}{c}\text { Peroxide } \\
\text { Value } \\
(\mathbf{m e q} / \mathbf{k g})\end{array}$ & $\begin{array}{c}\text { Saponification } \\
\text { Value } \\
(\mathbf{m g k O H} / \mathbf{g})\end{array}$ & $\begin{array}{c}\text { TPM } \\
(\%)\end{array}$ & $\begin{array}{c}\text { Heating } \\
\text { Value } \\
(\mathbf{k J} / \mathbf{k g})\end{array}$ \\
\hline Algae & 916.0 & 30.43 & 0.07 & 105.44 & 17.35 & 183.28 & 7.5 & 39657 \\
Sunflower & 921.7 & 33.08 & 0.21 & 122.68 & 10.39 & 192.73 & 4.0 & 39873 \\
Soybean & 923.3 & 32.63 & 0.12 & 129.65 & 25.45 & 195.06 & 8.0 & 39633 \\
Canola & 919.9 & 35.78 & 0.19 & 110.74 & 13.45 & 191.04 & 2.0 & 39755 \\
Corn & 921.9 & 34.33 & 0.26 & 115.36 & 6.09 & 189.72 & 6.0 & 39651 \\
Cotton & 922.3 & 33.96 & 0.19 & 114.19 & 9.09 & 195.27 & 6.5 & 39568 \\
Hazelnut & 917.1 & 37.74 & 0.19 & 86.91 & 12.88 & 188.33 & 2.5 & 39710 \\
Olive & 917.5 & 38.93 & 2.32 & 81.85 & 11.39 & 183.42 & 5.5 & 39617 \\
\hline
\end{tabular}

In Figure 6, density, viscosity, acid value and heating value values of different oils used in biodiesel production are compared.

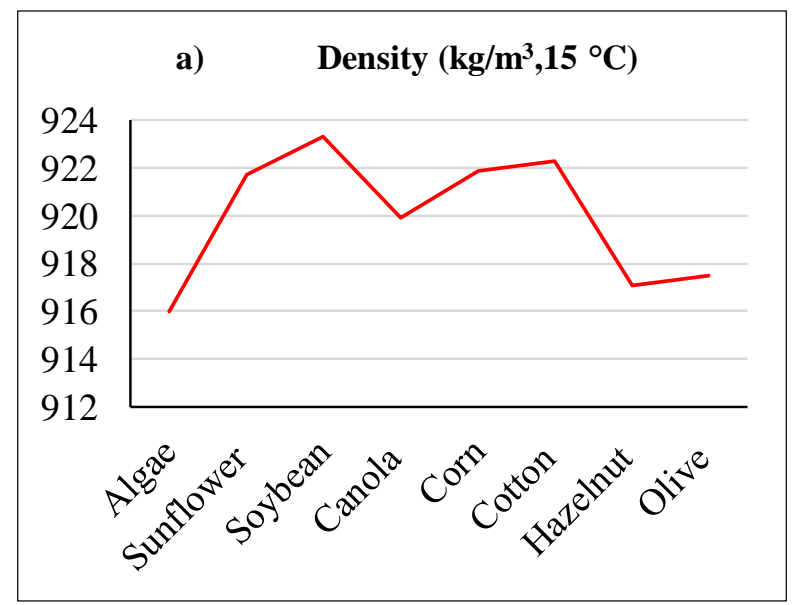

c) Acid Value (mg KOH/g)

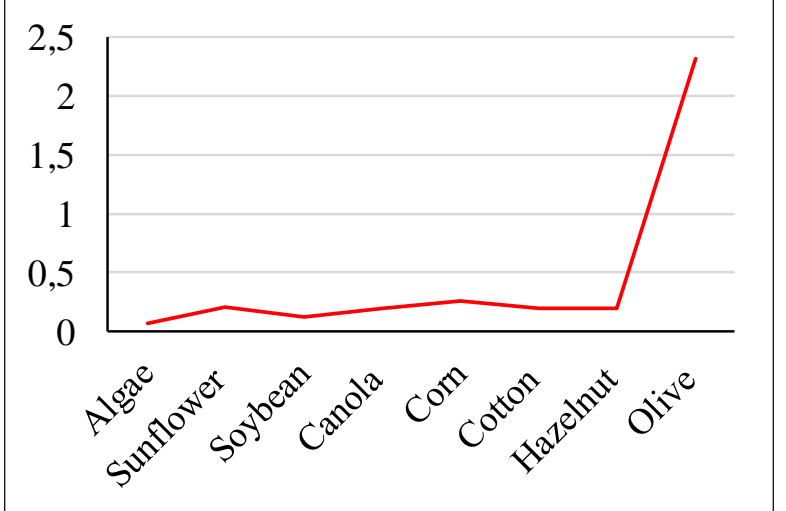

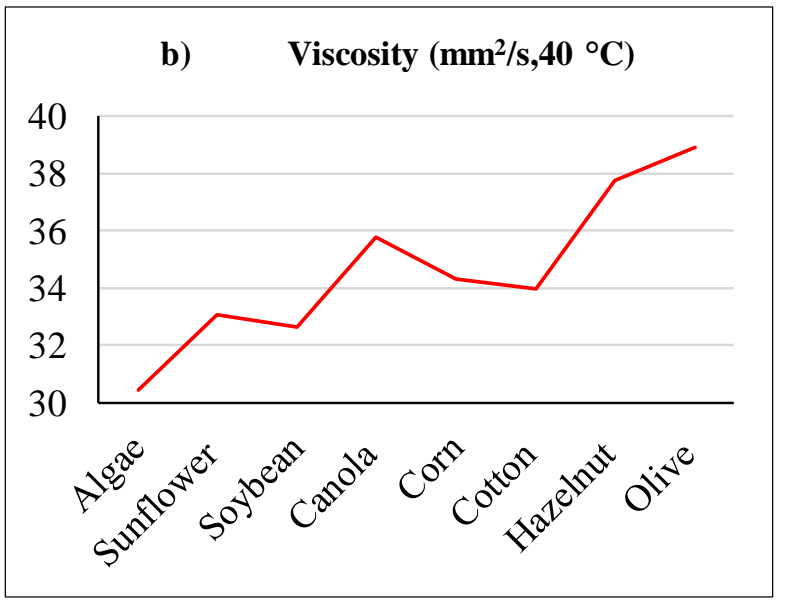

d) Heating Value $(\mathrm{kJ} / \mathrm{kg})$

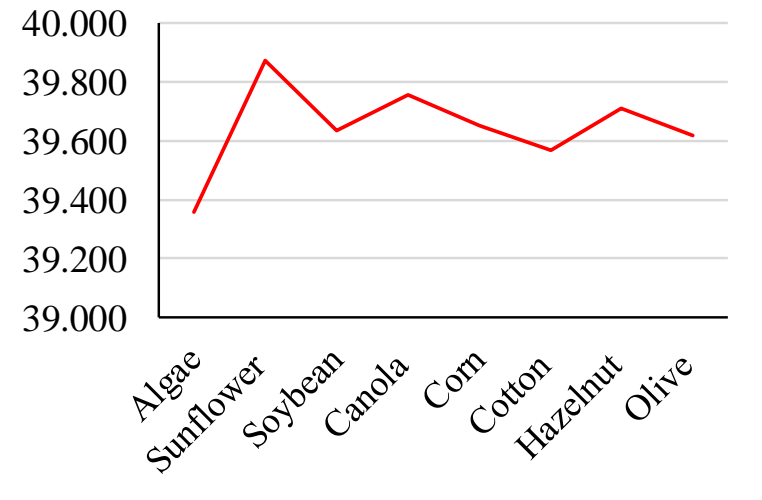

Figure 6. Density, viscosity, acid value and heating value values of different oils used in biodiesel production are compared 
When Figure 6 a) and b) are examined, it can be comprehend that the source whose density and viscosity values are the lowest is algae $\left(916 \mathrm{~kg} / \mathrm{m}^{3}, 30,43 \mathrm{~mm}^{2} / \mathrm{s}\right)$ and that this depends on the distributions of oil acids of the oils. One of the most important properties of oils used in biodiesel production is that of the acid values of the oil. When Figure $6 \mathrm{c}$ ) is examined, it can be clearly seen that algae oil has the lowest acid value $(0,07 \mathrm{mgKOH} / \mathrm{g})$, while olive oil has the highest acid value $(2,32 \mathrm{mgKOH} / \mathrm{g})$. And, this strengthens the view that algae oil is the most appropriate for biodiesel production. The energy values of fuels change depending on their calorific values. When the other oils used in the study are examined (Figure $6 \mathrm{c}$ )), it is seen that sunflower, canola, hazelnut and algae have had the highest calorific values as $39.873 \mathrm{~kJ} / \mathrm{kg}, 39.755 \mathrm{~kJ} / \mathrm{kg}, 39.710 \mathrm{~kJ} / \mathrm{kg}$ and $39.657 \mathrm{~kJ} / \mathrm{kg}$, respectively.

\section{Conclusion}

Many countries in the world are covering a large part of the energy they need from petroleum and importing the vast majority of that oil, which is a very critical problem, leading to energy dependency. For countries that import vast majority of Fossil-Origin Energy, such as our country, the matter of alternative energy sources, which can be produced with domestic resources, is a very critical issue. The fact that biofuels, which are becoming increasingly important in the world among alternative energy sources, can be used as an alternative to fossil based fuels causes attention to be drawn to this point. Increasingly becoming common throughout the world, biofuels contribute to countries' energy supply and provide alternative income and employment opportunities for producers of biofuel raw materials, especially in rural areas. When alternative fuels come into question in our country, biofuels, especially biodiesel, are at the forefront. With regard to biodiesel; it is foreseen that biodiesel will continue to be popular in the coming years, although there have been considerable criticisms such as the use of agricultural land for energy purposes, rising prices of food and agricultural products, and the tendency to do mono cultivation. The use of vegetable and animal oils with high cooking oil quality in the production of biodiesel means the extra cost for countries that import a large part of their oil needs. Especially in the face of rising food prices, the search for environmentally friendly energy sources has been accelerated without touching existing resources and using agricultural land. In this context, a lot of extensive studies have recently been carried out on the production of biodiesel from different algae species. The fact that some algae species have more fat than field crops and are easier to grow, and are not affected by changing seasons and climatic conditions, and can be grown in high quantities in a short period of time make them advantageous fuels. Nevertheless, the fact that agricultural lands are not used during their growing, and that they can reproduce even in very small areas, and that they do not need fertile soil for their development, and that they can grow in small ponds, and adapt to desert conditions are their most important advantages. When oil contents of the oils used in biodiesel production and oil amount obtained per hectare/year and the area in $\mathrm{m}^{2}$ necessary for producing one litre of biodiesel and biodiesel amounts obtainable for per hectare/year are examined, it is seen that algae has been established to have the highest oil content with 70\%, which is followed by Algae MOC with 50\% and Jute with $48 \%$. In addition, it has been determined that algae (HOC, MOC and LOC) have the highest yield compared with other sources in oil and biodiesel yield obtained per hectare/year. Moreover, it is seen that while Algae HOC needed for 1 litre biodiesel yield is $0,1 \mathrm{~m}^{2}$, it is $56 \mathrm{~m}^{2}$ for maize. It is clearly seen that alga are the most appropriate source for biodiesel production. When some of the critical values of oils used for biodiesel production are examined, it is seen that the source whose density and viscosity values are the lowest is algae with $916 \mathrm{~kg} / \mathrm{m}^{3}, 30,43 \mathrm{~mm}^{2} / \mathrm{s}$, and also the algae oil has the lowest acid value with $0,07 \mathrm{mgKOH} / \mathrm{g}$, while olive oil has the highest acid value with $2,32 \mathrm{mgKOH} / \mathrm{g}$. It is known 
that the energy values of fuels change depending on their calorific values. When the oils used in the study are examined, it can be seen that Sunflower, Canola, hazelnut and Algae have the highest caloric values with $39.873 \mathrm{~kJ} / \mathrm{kg}, 39.755 \mathrm{~kJ} / \mathrm{kg}, 39.710 \mathrm{~kJ} / \mathrm{kg}$ and $39.657 \mathrm{~kJ} / \mathrm{kg}$, respectively. When all data and analyses are taken into consideration, it is considered that some types of algae are quite appropriate for biodiesel production.

\section{References:}

[1] Fadly, F., (2019). Low-carbon transition: Private sector investment in renewable energy projects in developing countries. World Development, 122, 552-569.

[2] Turkey Petroleum Year 2016 Crude Oil and Natural Gas Sector Report.

[3] Zheng, W., Walsh, P.P. (2019). Economic growth, urbanization and energy consumption - A provincial level analysis of China. Energy Economics, 80, 153-162.

[4] Kim, Y.D., Frei, C., 2019. World Energy Scenarios, World energy council.

[5] Zarifi, F., Mahlia, T.M.I., Motasemi, F., Shekarchian, M., Moghavvemi, M. (2013). Current and future energy and exergy efficiencies in the Iran's transportation sector. Energy Conversion and Management, 74, 24-34.

[6] http://www.enerji.gov.tr/en-TR/Pages/Petrol, 2108.

[7] Yaşar, F., (2016).Production of biodiesel from algae oil and its use as an alternative fuel in a diesel engine, Doctoral Thesis, Batman Institute of Science, Batman.

[8] Knothe, G., (2005). Historical perspectives on vegetable oil-based diesel fuels. Book: The Biodiesel Handbook.

[9] Gebremariam, S.N., Marchetti, J.M., (2017). Biodiesel production technologies: review. AIMS Energy, 5(3): 425-457.

[10] Sabanci, A., Oren, M. N., Yasar, B. Ozturk, H., Atala, M., (2010). Evaluation of the agricultural sector in terms of biodiesel and bioethanol production in Turkey, Agricultural Engineering VII. Technical Congress.

[11] Şanl1, H, (2014). Characterization of waste frying oils and evaluation in biodiesel production, Doctorate Thesis, Kocaeli University. Institute of Science and Technology. Kocaeli.

[12] Singh, K., Kumar, S.P., Blumich, B., (2019). Monitoring the mechanism and kinetics of a transesterification reaction for the biodiesel production with low field H NMR spectroscopy. Fuel 243, 192-201.

[13] Sugozu, I., C. Oner, S. Altun, (2010). The performance and emissions characteristics of a diesel engine fueled with biodiesel and diesel fuel. Int. J. Eng. Res. Dev., Vol. 2.

[14] Altun, Ş., Yaşar, F., (2013). Biodiesel production from leather industry wastes as an alternative feedstock and its use in diesel engines. Energy Exploration \& amp; Exploitation, 31 (5), 759-770.

[15] Knothe, G., (2006). Analyzing biodiesel: Standards and other methods. Journal of the American Oil Chemists' Society, 83, 823-833.

[16] Öğüt, H., Oğuz, H., (2006). The fuel of the third millennium biodiesel. Book, 48-49.

[17] Akin, E., (2005).Turkey biofuels (biodiesel-bioethanol) report, Ankara.

[18] Öztürk, Ö., (2007).Investigation of the effects of biodiesel used without mixing in diesel engines on engine performance, Master Thesis, Y1ld1z Technical University, Institute of Science, Istanbul.

[19] Mutlu, L., Yavuz, H., Bayrakçeken, H., (2006). Meeting the performance of biodiesel fuels, 9. Burning Symposium, 40-49, Kirikkale.

[20] Altun, S., Öner, C., (2013).Gaseous emission comparison of a compression-ignition engine fueled with different biodiesels. Int. J. Environ. Sci. Technol, 10, 371-376. 
[21] Nişanc1, S., (2007). Experimental Investigation of Effects of Biodiesel Fuel Mixtures on Performance and Emission, M.Sc. Thesis, Y1ldız Technical University, Institute of Science, Istanbul.

[22] Türkay, S., (2005). Biodiesel production technologies, problems and suggestions on the current situation in biodiesel production workshop in Turkey, December 2, Ankara.

[23] Aries, M., (2011). Determination of the proper production of biodiesel and biodiesel plants that can be grown and grown technology in Turkey, $\mathrm{PhD}$ Thesis, Yildiz Technical University, Institute of Science and Technology, İstanbul.

[24] Artukoğlu, B.D., (2006). Development of biodiesel production and properties from animal waste oils, Graduate Thesis, Gazi University. Institute of Science, Ankara.

[25] www.mikroalg.com/tag/mikroalg-a, March 29, 2018.

[26] https://www.academia.edu/Alglerin Ecological Prevention, March 20, 2018.

[27] Mata, T. M., Martins, A. A., Caetano, N. S., (2010). Microalgae for biodiesel production and other applications: A review. Renewable and Sustainable Energy Reviews, 14, 217-232.

[28] www.en.wikipedia.org/wiki/Algae_fuel, 19 January 2018.

[29] Canzer M., Van Gerpen J., (2001). Biodiesel production from oils and fats with high free fatty acids. T. ASABE., 44, 1429-1436.

[30] Shen, Y., (2014). Carbon dioxide bio-fixation and wastewater treatment via algae photochemical synthesis for biofuels production, RSC Advances, 91.

[31] Wang B, Li Y, Wu N, Lan CQ., (2008). CO2 bio-mitigation using microalgae. Applied Microbiology and Biotechnology, 79 (5), 707-718.

[32] Lorenz, R.T., Cysewski, G. R., (2000). Commercial potential for haematococcus microalgae as a natural source of astaxanthin. Trends in Biotechnology, 18, 160-167.

[33] Rajvanshi, S., Sharma, M.P., (2012). Microalgae: A potential source of biodiesel, Journal of Sustainable Bioenergy Systems, 2, 49-59. 